Proc. Estonian Acad. Sci. Eng., 2006, 12, 3-1, 208-217

\title{
On the effect of correlation by the measurement of alternating voltage
}

\author{
Tatjana Barashkova \\ Tallinn University of Technology, Ehitajate tee 5, 19086 Tallinn, Estonia; \\ Tatjana.Barashkova@mail.ee \\ Received 24 May 2005, in revised form 7 October 2005

\begin{abstract}
The methods of estimation of the alternating voltage, which allow to increase the precision of measurement results in the case of correlated data obtained with different precision, are considered. For the comparison of the observation results of different times, a criterion of uniformity of correlation coefficients is proposed.
\end{abstract}

Key words: Fluke 792 A AC/CD transfer standard, Fisher transformation, correlation coefficient.

\section{INTRODUCTION}

By the estimation of any output quantity the tightness of relation of input quantities cannot be neglected. Therefore in practice it is necessary to estimate any dependence on sampling data with methods of statistics, which characterize the covariation of the dependent quantity. If linear dependence is investigated, the narrowness of the dependence needs to be estimated by means of selective correlation coefficients. It is impossible to confirm that the dependence is linear using a small volume of initial data. By deficiency of initial data, the functional dependence can be monotonously non-linear. Besides that, for the comparison of results of the measurements, executed at different times, it is expedient to apply the criterion of uniformity of different correlation coefficients. In measuring practice, the correlation coefficients are often neglected and it is assumed that measurement conditions are perfect and that the etalons possess ideal linear characteristics.

The Null Method $\left[{ }^{1}\right]$ by the measurement of an alternating voltage (RMS AC source of a voltage) is based on the linearity of the source of direct voltage (DC source of a voltage) with the best characteristics (Fluke 792 A AC/DC transfer 
standard and AC source of a voltage). Linearity of the transfer standard of a unit of voltage and linearity of a DC source of a voltage need to be checked up. Besides that, as conditions in measuring laboratories are different, the Null Method of measurement of the RMS AC source of a voltage cannot be considered universal. In this paper a version of the system of covariance calculation is presented, which leads to precise measurement results and is based on the least squares method, on the criteria of uniformity of several correlation coefficients and on the "expert-statistical" method.

Application of the above mentioned methods has allowed us to increase the reliability of the results of measurements of alternating current voltage.

\section{THE LEAST SQUARES METHOD}

Doubts in the linearity of a DC source of a voltage and Fluke 792 A AC/DC transfer standard can be disseminated by means of the least squares method. It is expedient to check up the efficiency of this method in the experiment with an unknown alternating voltage source (AC voltage source). AC and DC voltages are compared, using Fluke $792 \mathrm{~A}$. The suitable limit of measurement $792 \mathrm{~A}$ is chosen. Unknown AC voltage of known frequency, for example $50 \mathrm{~Hz}$, is fed on the input of the transfer standard $792 \mathrm{~A}$. DMM multimeter indication is stabilized and recorded. The forward and reverse DC voltages, which correspond to the level of AC voltage, are consistently fed to the input of the 792 A etalon. Values of alternating voltage are adjusted to the value corresponding to DMM indication. These values are fixed. The average value of the DMM indication, corresponding to the forward and reverse DC voltage, is determined. DMM indications at the alternating and the average direct voltage on the input of Fluke 792 A are recorded. Similar measurements are carried out in an interval from 1 up to $10 \mathrm{~V}$ within five days. The linearity between input voltage values $\left(U_{0 \approx}, U_{0 \equiv}\right)$ and approximately equal output voltage values $\left(U_{x \approx}, U_{x \equiv}\right)$ is described using unknown parameters of regression $\left[{ }^{2,3}\right]$ :

$$
\begin{aligned}
& U_{x \approx}=a_{\approx}+\frac{\mathrm{d} U_{x \approx}}{\mathrm{d} U_{0 \approx}} U_{0 \approx}, \\
& U_{x \equiv}=a_{\equiv}+\frac{\mathrm{d} U_{x \equiv}}{\mathrm{d} U_{0 \equiv}} U_{0 \equiv} .
\end{aligned}
$$

The problem of optimum choice of the parameters of regression is formulated as follows:

$$
L=\sum_{i=1}^{n}\left(U_{x i}-a-\frac{\mathrm{d} U_{x}}{\mathrm{~d} U_{0}} U_{0 i}\right)^{2} \rightarrow \min .
$$

Solution of the minimization problem leads to the following system of equations: 


$$
\begin{gathered}
a=\frac{\sum_{i=1}^{n} U_{x i}-\frac{\mathrm{d} U_{x}}{\mathrm{~d} U_{0}} \sum_{i=1}^{n} U_{0 i}}{n}=\bar{U}_{x}-\frac{\mathrm{d} U_{x}}{\mathrm{~d} U_{0}} \bar{U}_{0}, \\
\frac{\mathrm{d} U_{x}}{\mathrm{~d} U_{0}}=\frac{\sum_{i=1}^{n}\left(U_{0 i}-\bar{U}_{0}\right)\left(U_{x i}-\bar{U}_{x}\right)}{\sum_{i=1}^{n}\left(U_{0 i}-\bar{U}_{0}\right)^{2}},
\end{gathered}
$$

where $\bar{U}_{x}, \bar{U}_{0}$ express average values of the functions.

Parameters of regression $a$ and $\mathrm{d} U_{x} / \mathrm{d} U_{0}$ completely define the position of a straight line on the coordinate plane. The choice of dependent and independent variables essentially affects the parameters of this line. We shall consider two direct regressions

$$
\begin{aligned}
& U_{0}=a^{0}+\left(\frac{\mathrm{d} U_{0}}{\mathrm{~d} U_{x}}\right)^{0} U_{x}, \\
& U_{x}=a^{x}+\left(\frac{\mathrm{d} U_{x}}{\mathrm{~d} U_{0}}\right)^{x} U_{0} .
\end{aligned}
$$

Generally the factors of regression are related by the equations

$$
\begin{gathered}
a^{0}=-a^{x} \frac{\mathrm{d} U_{0}}{\mathrm{~d} U_{x}}, \\
\left(\frac{\mathrm{d} U_{0}}{\mathrm{~d} U_{x}}\right)^{0}\left(\frac{\mathrm{d} U_{x}}{\mathrm{~d} U_{0}}\right)^{x}=r^{2}, \quad \sqrt{\left(\frac{\mathrm{d} U_{0}}{\mathrm{~d} U_{x}}\right)^{0}\left(\frac{\mathrm{d} U_{x}}{\mathrm{~d} U_{0}}\right)^{x}}=r .
\end{gathered}
$$

If the above shown direct regressions are identical, the correlation coefficient is equal to unity. We shall define estimations of variances as

$$
\begin{aligned}
& s^{2}\left[\left(\frac{\mathrm{d} U_{x}}{\mathrm{~d} U_{0}}\right)^{x}\right]=\frac{\sum_{i=1}^{n}\left(U_{x i}-a^{x}-\left(\frac{\mathrm{d} U_{x}}{\mathrm{~d} U_{0}}\right)^{x} U_{0 i}\right)^{2}}{(n-2) \sum_{i=1}^{n}\left(U_{0 i}-\bar{U}_{0}\right)^{2}}, \\
& s^{2}\left[\left(\frac{\mathrm{d} U_{0}}{\mathrm{~d} U_{x}}\right)^{0}\right]=\frac{\sum_{i=1}^{n}\left(U_{0 i}-a^{0}-\left(\frac{\mathrm{d} U_{0}}{\mathrm{~d} U_{x}}\right)^{0} U_{x i}\right)^{2}}{(n-2) \sum_{i=1}^{n}\left(U_{x i}-\bar{U}_{x}\right)^{2}},
\end{aligned}
$$




$$
s^{2}[r]=\frac{1}{4}\left[s^{2}\left[\left(\frac{\mathrm{d} U_{0}}{\mathrm{~d} U_{x}}\right)^{0}\right]\left(\frac{\mathrm{d} U_{x}}{\mathrm{~d} U_{0}}\right)^{x} /\left(\frac{\mathrm{d} U_{0}}{\mathrm{~d} U_{x}}\right)^{0}+s^{2}\left[\left(\frac{\mathrm{d} U_{x}}{\mathrm{~d} U_{0}}\right)^{x}\right]\left(\frac{\mathrm{d} U_{0}}{\mathrm{~d} U_{x}}\right)^{0} /\left(\frac{\mathrm{d} U_{x}}{\mathrm{~d} U_{0}}\right)^{x}\right] .
$$

Equation (8) can be written as

$$
s^{2}[r]=\frac{1}{4}\left(\frac{\sum_{i=1}^{n}\left(U_{x i}-a^{x}-\left(\frac{\mathrm{d} U_{x}}{\mathrm{~d} U_{0}}\right)^{x} U_{0 i}\right)^{2}}{(n-2) \sum_{i=1}^{n}\left(U_{x i}-\bar{U}_{x}\right)^{2}}+\frac{\sum_{i=1}^{n}\left(U_{0 i}-a^{0}-\left(\frac{\mathrm{d} U_{0}}{\mathrm{~d} U_{x}}\right)^{0} U_{x i}\right)^{2}}{(n-2) \sum_{i=1}^{n}\left(U_{0 i}-\bar{U}_{0}\right)^{2}}\right) .
$$

The model is more adequate when the variances are small.

On the basis of the experimental data, received by means of the transfer standard of unity of the voltage Fluke 792 A, the difference between the voltages of the alternating and direct current $\delta^{\prime}$ is calculated using the least squares method. It is expedient to compare the received values with apparent error $\delta$ of the AC voltage source. Results of such a comparison, using experimental data of one day of measurements, are presented in Table 1 and Fig. 1.

The apparent error of the AC voltage source (Fig. 1) is bigger than the relative difference between voltages of alternating and direct current $\delta^{\prime}$, calculated with the least squares method. That proves the expediency of the least squares method by calibration of the alternating voltage source.

\begin{tabular}{|c|c|c|c|c|c|c|}
\hline $\begin{array}{c}\text { Range } \\
\mathrm{V}\end{array}$ & $\begin{array}{c}U_{x \approx} \\
\mathrm{V}\end{array}$ & $\begin{array}{c}U_{0 \approx} \\
\mathrm{V}\end{array}$ & $\begin{array}{c}U_{x \equiv} \\
\mathrm{V}\end{array}$ & $\begin{array}{c}U_{0 \equiv} \\
\mathrm{V}\end{array}$ & $\begin{array}{c}\delta=\frac{U_{0 \approx}-U_{0 \equiv}}{U_{0 \equiv}} \\
\times 10^{6}\end{array}$ & $\begin{aligned} \delta^{\prime}= & \frac{U_{0 \approx}^{\prime}-U_{0 \equiv}^{\prime}}{U_{0 \equiv}^{\prime}} \\
& \times 10^{6}\end{aligned}$ \\
\hline 1 & 0.91272248 & 10 & 0.91272226 & 9.999710 & 29 & 23 \\
\hline 2 & 0.82148018 & 9 & 0.82147801 & 8.999700 & 33 & 25 \\
\hline 3 & 0.73022863 & 8 & 0.73022799 & 7.999750 & 31 & 24 \\
\hline 4 & 0.63898620 & 7 & 0.63898690 & 7.000200 & 29 & 22 \\
\hline 5 & 0.54769387 & 6 & 0.54769273 & 5.999791 & 35 & 26 \\
\hline 6 & 0.45641487 & 5 & 0.45641467 & 4.999860 & 28 & 25 \\
\hline 7 & 0.36509764 & 4 & 0.36509701 & 3.999830 & 43 & 28 \\
\hline 8 & 0.27380322 & 3 & 0.27380349 & 2.999890 & 37 & 27 \\
\hline 9 & 0.18248528 & 2 & 0.18248517 & 1.999900 & 50 & 33 \\
\hline 10 & 0.09111343 & 1 & 0.09111147 & 0.999960 & 40 & 65 \\
\hline \multicolumn{4}{|c|}{$\begin{array}{l}\left(U_{0 \approx}\right)_{i 1}=89 \times 10^{-5}+10.95\left(U_{x \approx}^{\prime}\right)_{i 1} \\
\left(U_{x \approx}\right)_{i 1}=-8.1 \times 10^{-5}+0.091\left(U_{0 \approx}^{\prime}\right)_{i 1} \\
r=0.998\end{array}$} & \multicolumn{3}{|c|}{$\begin{array}{l}\left(U_{0 \equiv}\right)_{i 1}=87 \times 10^{-5}+10.95\left(U_{x \equiv}^{\prime}\right)_{i 1} \\
\left(U_{x \equiv}\right)_{i 1}=-7.9 \times 10^{-5}+0.091\left(U_{0 \equiv}^{\prime}\right)_{i 1} \\
r=0.998\end{array}$} \\
\hline
\end{tabular}

Table 1. Complete results of calculation of $\boldsymbol{\delta}$ and $\boldsymbol{\delta}^{\prime}$ 


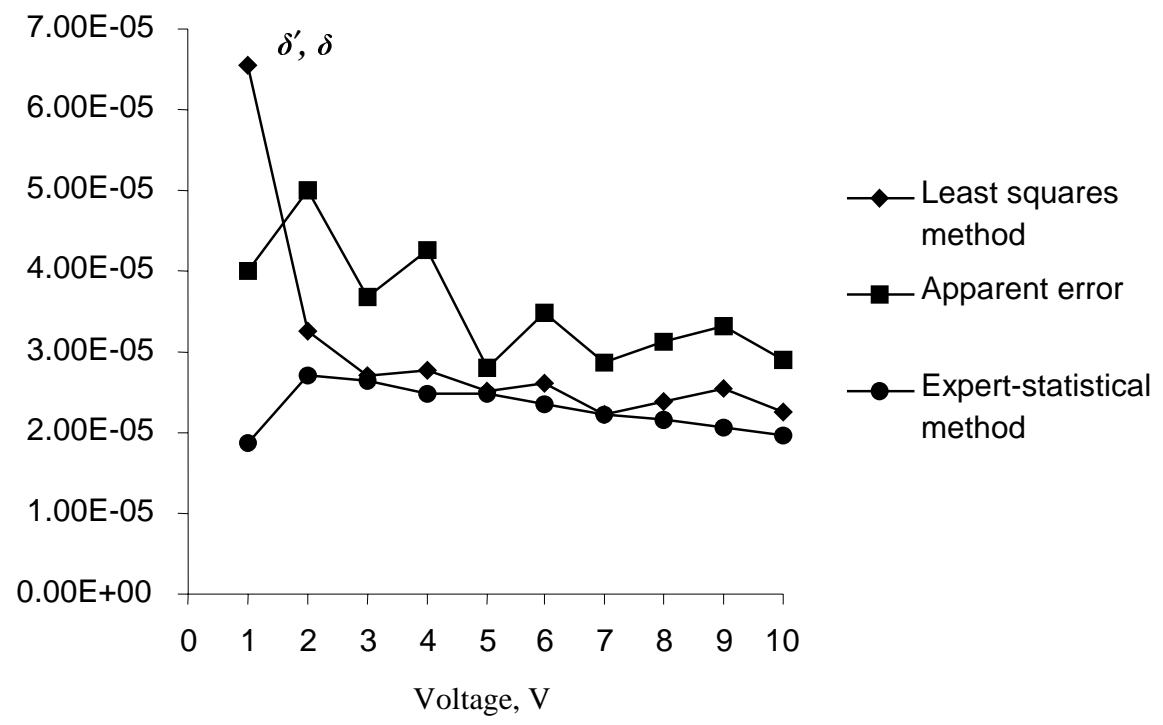

Fig. 1. Complete result of calculation of $\boldsymbol{\delta}$ and $\boldsymbol{\delta}^{\prime}$ from experimental data of one day of measurements.

\section{CRITERION OF UNIFORMITY OF DIFFERENT FACTORS OF CORRELATION}

The conclusion about expediency of application of the least squares method by calibration of alternating voltage was made on the basis of experimental data of one day of measurements. For statistical check of this conclusion the criterion of uniformity of different correlation coefficients $\left[{ }^{4}\right]$, using Fisher's distribution, is applied. Using measurement results of the relative difference $\delta^{\prime}$ (Fig. 2), carried out within five days, it is possible to regard as statistically insignificant the difference of the values of the selective correlation coefficient $r\left(U_{x \approx}, U_{x \equiv}\right)$. Indeed, relationship between $U_{x \approx}$ and $U_{x \equiv}$ is characterized by the correlation coefficient

$$
r\left(U_{x \approx}, U_{x \equiv}\right)=\frac{u\left(U_{x \approx}, U_{x \equiv}\right)}{u\left(U_{x \approx}\right) \cdot u\left(U_{x \equiv}\right)}
$$

where $u$ is the uncertainty of the measured value.

For the chosen limit of measurement in the formula (10), the correlation coefficients $r_{j}(j=1 \ldots 5)$ of samples of volumes $n_{j}$ are determined. Use of $r_{j}^{\prime}-$ the transformed value of $r_{j}$ - is preferable for the check of the importance of the correlation dependence when number of measurements $n_{j}$ is small. By means of Fisher's transform the above used estimations of the selective correlation coefficient according to five days of measurements were determined: 


$$
r_{j}^{\prime}\left(U_{x \approx}, U_{x \equiv}\right)=\operatorname{arcth} r_{j}\left(U_{x \approx}, U_{x \equiv}\right)=\frac{1}{2} \ln \frac{1+r_{j}\left(U_{x \approx}, U_{x \equiv}\right)}{1-r_{j}\left(U_{x \approx}, U_{x \equiv}\right)} .
$$

As the best estimation of the correlation coefficient, the following formula was used

$$
r^{\prime}=\frac{\sum_{j=1}^{5}\left(n_{j}-3\right) \operatorname{arcth} r_{j}}{\sum_{j=1}^{5}\left(n_{j}-3\right)} .
$$

For checking the hypothesis about the absence of distinctions in initial data, $\bar{\chi}^{2}$ was calculated:

$$
\bar{\chi}^{2}=\sum_{j=1}^{5}\left(n_{j}-3\right) \operatorname{arcth}^{2} r_{j}-\frac{\left[\sum_{i=1}^{5}\left(n_{j}-3\right) \operatorname{arcth} r_{j}\right]^{2}}{\sum_{i=1}^{5}\left(n_{j}-3\right)} .
$$

In Table 2 the calculation of (13) is presented.

Since calculated from Eq. (13) $\bar{\chi}^{2}$ is smaller than the critical value of $\chi^{2}$, the initial data of five days of measurements may be considered to be statistically homogeneous.

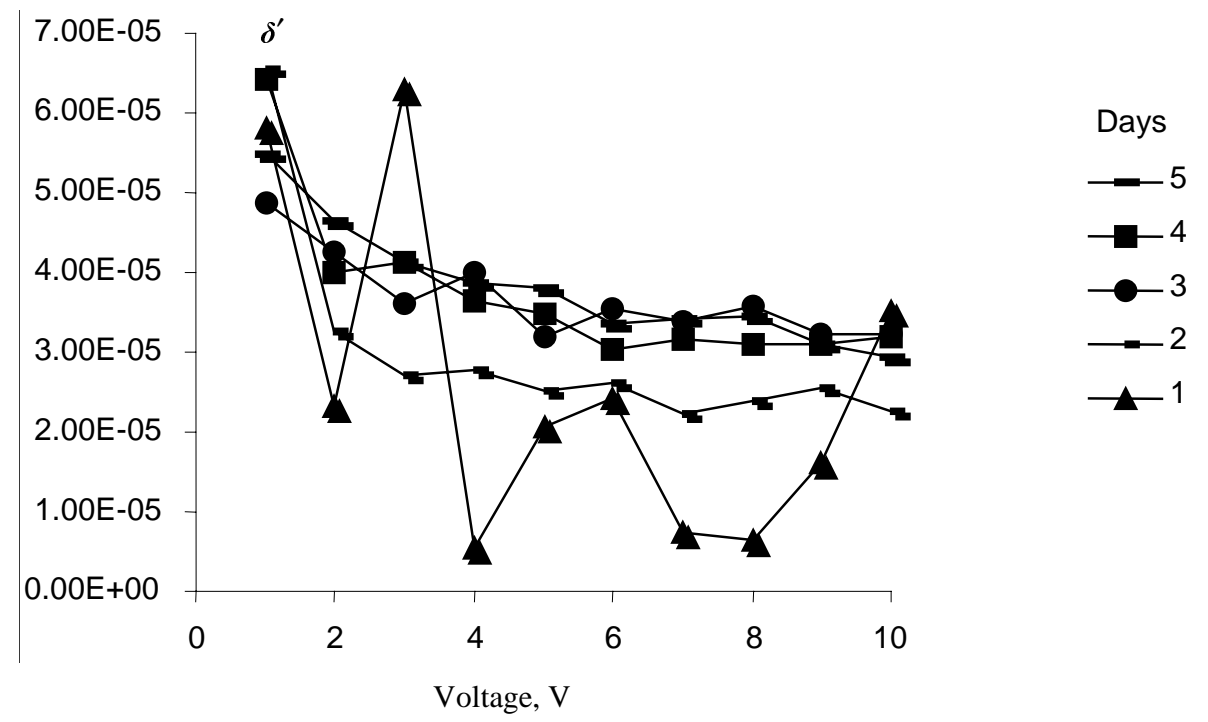

Fig. 2. Complete results of calculation of $\boldsymbol{\delta}^{\prime}$ with the least squares method from experimental data of five days of measurements. 
Table 2. Complete results of calculation of $\bar{\chi}^{2}$

\begin{tabular}{c|c|r|r|r|r|r}
\hline $\begin{array}{c}\text { Day } \\
j\end{array}$ & $n_{j}$ & $r_{j}$ & $r_{j}^{\prime}$ & $n_{j}-3$ & $\left(n_{j}-3\right) r_{j}^{\prime}$ & $\left(n_{j}-3\right)\left(r_{j}^{\prime}\right)^{2}$ \\
\hline 1 & 10 & -0.5768021 & -0.6576571 & 7 & -4.6035997 & 3.02759001 \\
2 & 10 & 0.4699071 & 0.5099511 & 7 & 3.5696577 & 1.82035090 \\
3 & 10 & -0.4120857 & -0.4381209 & 7 & -3.0668465 & 1.34364963 \\
4 & 10 & 0.1319427 & 0.1327164 & 7 & 0.9290150 & 0.12329556 \\
5 & 10 & -0.0757765 & -0.0759220 & 7 & -0.5314543 & 0.04034909 \\
$\bar{\chi}^{2}=5.96$ & & & 35 & -3.7032277 & 6.3552352
\end{tabular}

\section{THE EXPERT-STATISTICAL METHOD}

The general number of parameters, influencing the investigated value of an alternating voltage, is large. If these parameters are registered at every $i$-limit of measurements, the multivariate measurements will turn out. It is necessary to subject these available multivariate measurements to statistical processing to obtain a more reliable objective function:

$$
\begin{aligned}
U_{0 \approx}^{\prime} & =f\left(U_{x \approx}, U_{x \equiv}, U_{0 \approx}, U_{0 \equiv}\right) \\
& =\alpha+\beta_{1} U_{x \approx}+\beta_{2} U_{x \equiv}+\beta_{3} U_{0 \approx}+\beta_{4} U_{0 \equiv} .
\end{aligned}
$$

Expert-statistical method $\left[{ }^{5,6}\right]$ permits to receive the best estimation of the value of an alternating voltage of $50 \mathrm{~Hz}$ frequency, dependent on the correlated inputs.

4.1. Statistical part of initial data. As it was already mentioned above, input variables $U_{x \approx}, U_{x \equiv}, U_{0 \approx}$ and $U_{0 \equiv}$ were measured at each $i$-limit of measurements on every $j$ th day of the experiment. Therefore the statistical part of the initial data is presented in the form

$$
\boldsymbol{X}^{j}=\left(\begin{array}{l}
U_{x \approx}^{1}, U_{x \approx}^{2}, \ldots, U_{x \approx}^{i} \\
U_{x \equiv}^{1}, U_{x \equiv}^{2}, \ldots, U_{x \equiv}^{i} \\
U_{0 \cong}^{1}, U_{0 \cong}^{2}, \ldots, U_{0 \cong}^{i} \\
U_{0 \equiv}^{1}, U_{0 \equiv}^{2}, \ldots, U_{0 \equiv}^{i}
\end{array}\right) .
$$

4.2. Expert part of the initial data concerns the estimations of $U_{0 \approx}^{\prime}$, received after corresponding statistical processing of the expert data (Table 1). Data about $U_{0 \approx}^{\prime}$ are presented in the following form:

$$
\boldsymbol{Y}_{i j}=\left(\begin{array}{l}
\left(\boldsymbol{U}_{0 \approx}^{\prime}\right)_{11},\left(\boldsymbol{U}_{0 \approx}^{\prime}\right)_{21}, \ldots,\left(\boldsymbol{U}_{0 \approx}^{\prime}\right)_{i 1} \\
\left(\boldsymbol{U}_{0 \approx}^{\prime}\right)_{12},\left(\boldsymbol{U}_{0 \approx}^{\prime}\right)_{22}, \ldots,\left(\boldsymbol{U}_{0 \approx}^{\prime}\right)_{i 2} \\
\ldots \ldots \ldots \ldots \ldots \ldots \ldots \ldots \ldots \ldots \ldots \ldots, \ldots \ldots \\
\left(\boldsymbol{U}_{0 \approx}^{\prime}\right)_{1 j},\left(\boldsymbol{U}_{0 \approx}^{\prime}\right)_{2 j}, \ldots,\left(\boldsymbol{U}_{0 \approx}^{\prime}\right)_{i j}
\end{array}\right),
$$


where $\left(\boldsymbol{U}_{0 \approx}^{\prime}\right)_{i j}$ is the expert estimation of the alternating voltage, received in the frequency range of $50 \mathrm{~Hz}$ ( $i$ is limit of the measurement on the $j$ th day of the experiment).

4.3. Estimating unknown parameters of the objective function is reduced to the usual scheme of the regression analysis. The criterion of the least squares method $\left[^{5}\right]$ assesses the parameters of the objective function as the solution of the optimization problem of the kind

$$
\sum_{j=1}^{5} \sum_{i=1}^{10} \frac{1}{\sigma_{i j}^{2}}\left[\left(U_{0}^{\prime}\right)_{i j}-f\left(U_{x \approx}, U_{x \equiv}, U_{0 \approx}, U_{0 \equiv}\right)\right]^{2} \rightarrow \min ,
$$

where $\sigma_{i j}$ characterizes uncertainty of the estimation at the $i$-limit of measurements on the $j$ th day of the experiment.

Solution of the optimization problem (16) is

$$
\begin{aligned}
U_{0 \approx}^{\prime}= & 3.17 \times 10^{-5}+0.092794403 U_{x \approx}-0.092794692 U_{x \equiv} \\
& +6.67365 \times 10^{-7} U_{0 \approx}+0.983076135 U_{0 \equiv} .
\end{aligned}
$$

The obtained functional dependence allowed us to determine the contribution of each input quantity to the uncertainty of the alternating voltage estimation that in turn led to the improvement of the model of measurement (Fig. 3.).

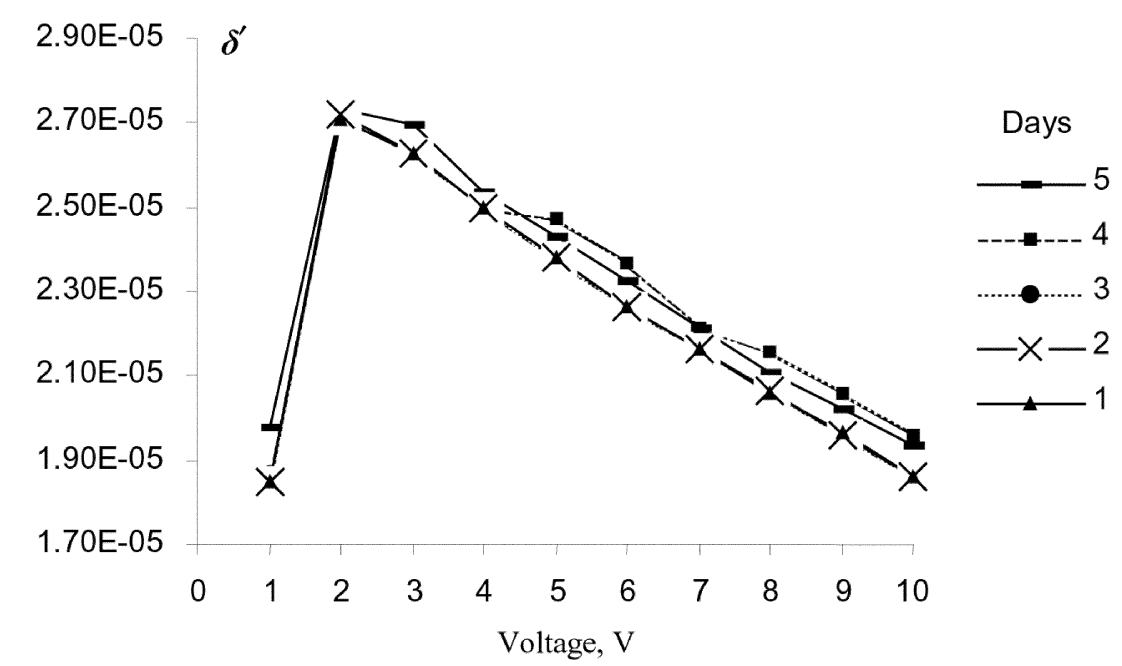

Fig. 3. Complete result of calculation of $\boldsymbol{\delta}^{\prime}$ with the expert-statistical method from experimental data of five days of measurements. 


\section{CONCLUSIONS}

The presented version of the system of alternating voltage calculation allows to establish in Estonia the reference standard of alternating voltage from $100 \mathrm{mV}$ up to $1000 \mathrm{~V}$ within the limits of frequencies from $10 \mathrm{~Hz}$ up to $1 \mathrm{MHz}$ on the basis of the transfer standard of unity of voltage Fluke 792 A. Experimental investigation of this standard and results of the international checking have shown that the reference standard can be used for an alternating voltage, for example, from 1 up to $10 \mathrm{~V}$ with the relative expanded uncertainty from $17 \times 10^{-6}$ up to $28 \times 10^{-6}$.

\section{ACKNOWLEDGEMENTS}

The author expresses her thanks to Andrei Pokatilov and Toomas Kübarsepp, Metrosert Ltd.

\section{REFERENCES}

1. Inglis, B. D. Standards for ac-dc transfer. Metrologia, 1992, 29, 191-199.

2. Sasaki, H. and Takahashi, K. Development of a high-precision AC-DC transfer standard using the fast-reversed DC method. Researches of the Elektrotechnical Laboratory, Agency of Industrial Science and Technology, Ibaraki, No. 989, 1999.

3. Aleksakhin, S. V., Baldin, A. B., Nikolaev, A. B. and Stroganov, V. Yu. Applied Statistical Analysis. Prioritet, Moscow, 2001 (in Russian).

4. Aivazian, S. A., Enyukov, I. S. and Meshalkin, L. D. Applied Statistics: Correlation Analysis. Finance and Statistics, Moscow, 1985 (in Russian).

5. Aivazian, S. A., Bukhshtaber, V. M., Enyukov, I. S. and Meshalkin, L. D. Applied Statistics: Classification and Dimensionality Reduction. Finance and Statistics, Moscow, 1988 (in Russian).

6. Barachkova, T. and Laaneots, R. L'expérience de covariation entre des valeurs devant les mesures d'une tension alternative. In 12ème congrès international de métrologie. Lyon, 2005 .

\section{Korrelatsiooni uurimine vahelduvpinge mõottmisel}

\section{Tatjana Baraškova}

On vaadeldud sellist kovariatsioonide hindamise metoodikat, mis võimaldab mõõtmistulemusi täpsustada ka erineva täpsusega ja korreleeruvate vaatlustulemuste puhul. Erineval ajal saadud mõõtmistulemuste võrdlemiseks on kasutatud korrelatsioonikoefitsientide homogeensuse kriteeriumi.

On teada, et ühegi väljundi hindamisel ei ole võimalik kindlalt väita, et seejuures võib lähteandmete sidemetiheduse arvestamata jätta. Seetõttu on praktiliselt igat uuritavat sõltuvust vajalik hinnata väljavõtteliste andmete alusel, kasuta- 
des seejuures statistilisi hindamismeetodeid, mis iseloomustavad sõltuvate suuruste korrelatsiooni. Näiteks kui uuritav sõltuvus on oletuslikult lineaarne, siis hinnatakse sõltuvate sisendandmete sidemetihedust väljavõttelise korrelatsioonikoefitsiendi abil statistilisel meetodil või kogemuslikult. Seda, et sõltuvus on lineaarne, ei saa kinnitada, kasutades väikesemahulist lähteandmete hulka. Analoogselt ei saa kindlalt väita, omamata vajalikul hulgal statistilist materjali, et sõltuvad juhuslikud suurused alluvad normaaljaotuse seadusele. Lähteandmete vähesuse korral võib sisendsuuruste funktsionaalne sõltuvus olla monotoonselt mittelineaarne.

Artiklis on korrelatsioonianalüüsi tulemuste usaldatavuse suurendamiseks lahendatud järgmised ülesanded. On välja töötatud vahelduvpinge etaloni mudeli määramatuse hindamise meetodid nii erineva täpsusega kui ka korreleeruvate mõõtetulemuste jaoks. Mõõtemetoodikas on võetud kasutusele mitmemõõtmelise matemaatilise statistika meetodid vahelduvpinge ebastabiilsuse hinnangu vähendamiseks. On arvestatud vahelduvpinge mõõtetingimuste muutuvust juhul, kui ei ole teada mõõdetava suuruse täpset funktsionaalset sõltuvust nendest tingimustest. On analüüsitud võimalust alandada mõõtmiste valemi dimensiooni ja vähendada informatiivsemate näitajate arvu. On uuritud ka juhuslike hälvete mõju füüsikaliste suuruste vahelisele korrelatsioonikoefitsiendile vahelduvpinge mõõtmisel. 